\title{
Bridging the Theoretical Gap between Public Diplomacy and Cultural Diplomacy
}

\author{
Hwajung Kim
}

\begin{abstract}
As public diplomacy has undergone a paradigm shift in the information age, cultural diplomacy remains loosely defined as a strand of public diplomacy, yet there has been little explanation as to why this was so. Rather, cultural diplomacy has been underestimated in recent diplomatic activities. The combination of new public diplomacy and soft power has become the formula for how international cultural exchanges and programs work in contemporary diplomatic activities and has brought a new perspective on arts and culture as a means of soft power. The present study aims to uncover the missing pieces in cultural diplomacy as a subset of new public diplomacy and delves into what complicates the definition of cultural diplomacy. The study concludes that new cultural diplomacy should be considered as an intersectional concept of new public diplomacy and international cultural relations.
\end{abstract}

Key Words: public diplomacy, soft power, cultural diplomacy, international cultural relations

Qince the 9/11 terrorist attacks, public diplomacy has become a strong foreign policy tool for mutual understanding through two-way communications. Public diplomacy addresses foreign publics and thereby increases the soft power of a state. Despite public diplomacy having distinct origins in the United States, many countries have started paying enormous attention to public diplomacy as a key part of diplomatic practices to strengthen their own soft power. Thus, public diplomacy has spread throughout the world from Latin America to Eastern Europe and Asia as a means of capturing the hearts and minds of foreign

*Hwajung Kim(hwajungkim@ewha.ac.kr) is a lecturer on public diplomacy at the Graduate School of International Studies at Ewha Womans University. She received her Ph.D. from Ewha Womans University in 2016, receiving the best doctoral thesis prize from the university. Her research interests include soft power and cultural governance as well as public and cultural diplomacies. This paper reorganizes and rewrites the second chapter of her doctoral dissertation, "Effective Public-Private Partnerships in Cultural Diplomacy: A Case Study of Germany and South Korea.” 
publics. Furthermore, as public opinion has started to have an impact on foreign policy decision-making, publics have been gaining interest in foreign affairs and diplomacy. There has been an emergence of a broader literature in the field of foreign policy and more generalized insights from practitioners and about publics. Today, public diplomacy is hotly contested not only by scholars and practitioners but also by diverse actors from the general public.

The term 'public diplomacy' has been widely used since the First World War, and it has been referred to as publicly-brokered peace covenants or the propaganda of the Cold War. Education, arts and cultural exchange programs and international broadcasting were the main tools for conducting public diplomacy, and individual governments spent large amounts of money particularly on education and cultural exchange programs up through the end of the Cold War. In the post-9/11 era, definitions of public diplomacy-the so-called 'new' public diplomacy-have expressed a strong foreign policy orientation towards mutual understanding, which is reflected in terms such as 'engagement,' 'relationship building' or 'two-way communications' (Melissen 2005). Cultural diplomacy has become a linchpin of public diplomacy with the rise of concern for soft power as globalization-in the sense of connectivity in economic and cultural life around the world-has been growing for several decades (Kim 2011). There is no doubt about the positive contribution of cultural diplomacy to national image, branding, and social cohesion; thus, cultural diplomacy has been regarded as a subset of public diplomacy by many public diplomacy scholars.

However, currently there is no compelling research explaining why this is so. Rather, different views on cultural diplomacy and public diplomacy, and the relationship between the two, complicate our precise understanding of what cultural diplomacy means. For example, 'engagement diplomacy' embraces neither public diplomacy nor cultural diplomacy, while 'contemporary diplomacy' puts them in different domains. From other perspectives, cultural diplomacy is regarded as either the core of public diplomacy or as a subset of public diplomacy, as previously mentioned. This confusion-at least four different views on the linkages of cultural diplomacy and public diplomacycomes from the lack of theoretical research, and widens the gap between cultural diplomacy in academia and practice. It blurs where to draw the line between 'culture for the purpose of flourishing cultural assets, values and identities' and 'culture as a means of foreign policy and diplomatic activities.' Given these circumstances, it is imperative to create a proper conceptualization of cultural diplomacy, which requires more in-depth analysis.

This study aims to define this relationship, bridging the gap between public diplomacy and cultural diplomacy by contesting cultural diplomacy as a subset 
of public diplomacy, thus contributing to the theorizing on cultural diplomacy with the emergence of globalization and the informational age. Fundamental questions have arisen as to what the historical and contemporary aspects of cultural activities were in international relations in conjunction with a state's foreign policies and diplomacy, and how the growing attention on soft power has contributed to redefining cultural diplomacy in a contemporary context. Public diplomacy has its roots in international relations (IR), starting with the 'power and diplomacy' of realist thought, and further developing into the 'complex interdependence' and 'new institutionalism' of neoliberalism, and the issues of culture and identity dealt with in constructivism. Yet ironically, cultural diplomacy has not been rigorously studied by IR scholars since the end of the Cold War. In addition, recent scholars in the field of cultural diplomacy are multidisciplinary and have quite scattered views on the subject, rather than drawing from traditional IR theories. This study finds that the most profound research has been conducted by international historians, whose studies have affected scholars in a variety of different fields. Therefore, it is worthwhile to explore historians' points of view on cultural diplomacy, followed by an exploration of perceptions of IR scholars and cultural diplomacy scholars, consecutively. This study does not employ a comparative approach, but attempts to embrace various fields of study to explain why and in what ways cultural diplomacy has been considered as a subset of public diplomacy over time without sufficient theoretical groundings.

In exploring these issues, this study begins by examining paradigm shifts in public diplomacy in relation to the theoretical development of public diplomacy, and further explores how soft power and 'new' public diplomacy are interrelated. Secondly, this study investigates perspectives on cultural diplomacy from international historians, international relations scholars and cultural diplomacy experts to reveal inconsistencies in cultural diplomacy scholarship as a subset of new public diplomacy. Lastly, this study delves into how soft power can be incorporated into public and cultural diplomacies to conceptually and theoretically explain cultural diplomacy in a contemporary context.

\section{PARADIGM SHIFT IN PUBLIC DIPLOMACY}

\section{THEORETICAL DEVELOPMENT IN PUBLIC DIPLOMACY}

Public diplomacy's multidisciplinary conceptualization has been explored in the fields of communications and international public relations, marketing, foreign policy analysis, and diplomatic studies (Gilboa 2008; Gregory 2008; Melissen 
2013; Sharp 2013). Despite the vast amount of literature on public diplomacy from diverse disciplines, public diplomacy is also criticized for its lack of a theoretical infrastructure (Entman 2008). The multidisciplinary approaches to public diplomacy all tend to focus on public opinion, which results in communicative dimensions of diplomacy. As Melissen states, "Diplomacy has never been able to neglect public opinion" (Sharp 2013, 194).

For this reason, British communication and public relations scholars in the 1950 and 1960 s tried to include propaganda under the overarching concept of public relations, which was called "bad apples" by public relations scholars who were insisting that public relations was a form of diplomacy (L'Etang 2009, 609). In line with this scholarly debate, Tuch (1990) argued that public relations should be defined and considered in the context of globalization, and Signitzer and Coombs (1992) further develop the linkage between public relations and public diplomacy. Subsequently, scholars in communication studies contributed to the development of public diplomacy by applying the lens of communication to public diplomacy theory and practices (Leonard 2002; Jönsson and Hall 2003; van Ham 2008; Rasmussen 2009; Pamment 2011; Hayden 2013), or by incorporating national branding concepts using marketing points of view (Potter 2009). In recent studies, with the rise of private actors, a need for public-private partnerships has been strongly recommended as well (Pigman and Deos 2008; Cowan and Arsenault 2008). These scholarly efforts resulted in diverse public diplomacy models from Leonard (2002)1, Gilboa (2008), and Ordeix-Rigo and Duarte (2009). The concept of power in public diplomacy has been explored in Rasmussen's (2009) discursive influence model of normative power, although the normative expectations used have been criticized (Pamment 2011). In order to keep pace with advancing technology and global communications, the practice of public diplomacy has never been more integral to diplomatic initiatives (Melissen 2013).

By comparison, this study puts more weight on the perspectives of U.S. practitioners of U.S. foreign policy and public diplomacy, which brought a number of disciples to the field of public diplomacy studies, such as Joseph $\mathrm{Nye}^{2}$ and Christopher Ross. ${ }^{3}$ Against the backdrop of the end of the Cold War, with the United States as a unipolar power and anti-Americanism finding greater

1 Leonard's model caught the attention of international relations scholars, particularly after Nye (2004) adopted it into his analysis of soft power.

2 Nye coined the term "soft power" in 1990 and served in the U.S. government during the late 1970 and the 1990 .

3 Ross, who addressed strategic public diplomacy in U.S. foreign policy, was a former U.S. diplomat and served as ambassador in Algeria and Syria in the 1990s. 
expression around the world (Sanders 2011), practitioners predicted the demise of America as a superpower (Bryce 1889; Russell 1967). After noticing their neglect of public information with the abolishment of the U.S. Information Agency (USIA) and substantial budget cuts on cultural activities, American leaders turned to a more strategic foreign policy tool-public diplomacy (Nye 1990). Public diplomacy included what the United States should consider important to achieving foreign policy goals: a concern for foreign public opinion, interaction with private actors and interests, and communication through intercultural communications. Public diplomacy became a substitute for American foreign policy propaganda (Roberts 2006; Cull 2009; Gregory 2008). Public diplomacy then regained its practicality in U.S. foreign policy. In particular, the 9/11 terrorist attacks and the decline of the United States' image internationally stimulated practitioners and think tanks in the United States to transform the country's approach to diplomacy (Gregory 2008), as well as employing new forms of diplomatic dialogue and collaboration (Fitzpatrick 2011).

America had to reevaluate its use of public diplomacy in a post-Cold War, globalized world; while European countries were successfully using public diplomacy for a number of endeavors, the United States was seeing huge gaps in its initiatives (Gregory 2008). Particularly, European scholars such as Jan Melissen, Rhiannon Vickers, and James Pamment contributed to the theoretical development of public diplomacy by looking at unprecedented shifts in diplomatic practices, many mainly characterized by engaging non-government actors and private individuals, and changing diplomatic operations systems during the Information and Communication Technology (ICT) revolution at a time of rapid globalization. This standpoint stimulated various academic fields like social studies, cultural studies, and diplomatic studies, as well as inspiring public diplomacy scholars to have an even broader sense of public diplomacy. Noticeably, recent studies by European public diplomacy scholars have tended to consider the concept of public diplomacy as a government vis-à-vis the European Union, which is in line with considerations of European scholars on the role of diplomacy in the process of European integration (Cross and Melissen 2013). Despite public diplomacy being rooted in the American tradition, it can be argued that individual members of the European Union have conducted public diplomacy to cope with negative perceptions of the process of integration in foreign countries and have integrated public diplomacy as part of their foreign policies (Melissen 2005). This implies that public diplomacy should not be treated as merely one technique in an arsenal of foreign policy tools, but rather it should be taken as a paradigm shift in diplomacy. 
Although public diplomacy has become multidisciplinary, particularly in its theoretical development, it is imperative to know that the actual practice of public diplomacy is limited to information and cultural activities in the context of foreign affairs. As such, Tuch (1990) criticized then-U.S. public diplomacy as no different from traditional diplomacy and that its broad definition created unneeded complexity. He emphasizes the importance of learning experience and two-way communications in public diplomacy by considering public opinion and perceptions as integral elements of foreign policy. Tuch's argument about public diplomacy was solidified by the concept of soft power. Nye (2004) described public diplomacy as the ability of a state to make other states strive for common goals. This was done by helping states to see the positive aspects of a potential outcome and was very similar to the idea of soft power. Melissen (2005), however, saw public diplomacy as a tool for building soft power. Furthermore, Hocking (2005) believed that to connect soft power and public diplomacy was contradictory, as public diplomacy would be unnecessary if simple attraction using soft power was successful. Nevertheless, it is undeniable that soft power helped to develop public diplomacy in theory and practice.

\section{SOFT POWER AND NEW PUBLIC DIPLOMACY}

The concept of soft power was developed on the basis of what Peter Bachrach and Morton Baratz (1962) considered the second face of power. ${ }^{4}$ This concept differs from the traditional idea of hard power (military and economic power) in that soft power is wielded through attraction, persuasion, and cooperation. In today's globalized world, Nye argued that soft power was becoming increasingly more important than hard power. A major factor in the use of soft power is a state's ability to access large channels and amounts of information. Two other important factors in the growth of soft power include the closeness of the state's ideological culture to global norms and values, such as pluralism and liberalism. The closer a state's dominant ideology to global norms, the more soft power it should have. Secondly, as the credibility of a state increases, so should its soft power (Nye 2002).

However, public diplomacy without attractive contents of a nation's culture, values, and policies may generate a negative impact on the country (Nye 2008). Nye (2011) puts emphasis on the structural changes of dealing with information in the age of the Internet, where power is being diffused from states to nonstates actors, consequently making public diplomacy more complicated.

4 Nye first coined the term "soft power" in his 1990 book, Bound to Lead: The Changing Nature of American Power. 
Melissen (2005) successfully adopted communications into public diplomacy by stressing its importance as a revolution in international relations. It was enough to fill the gaps in Rhiannon Vikers' (2004) blurry distinction between traditional diplomacy and 'new' public diplomacy. Since then, communicative aspects of public diplomacy have become important parts of the discourse among IR scholars and have been integrated into conceptualizations of the new public diplomacy. Gregory explicitly refers to public diplomacy as "a communication instrument used in governance broadly defined” $(2008,276)$.

In describing the characteristics of new public diplomacy, Fitzpatrick (2011) emphasizes that, due to increasing globalization, states are losing their traditional control over some aspects of politics and government; however, nonstate actors are gaining more control over world affairs (Batora 2005; Melissen 2005; Cull 2009). This creates a new dynamic where states must have two-way dialogues with foreign publics instead of one-way monologues. States must also consider their communications with domestic publics in order to create uniform initiatives (Zaharna 2010). The importance of including domestic publics in public diplomacy actions cannot be understated, as globalization and worldwide communication make the boundaries between foreign and domestic publics less clear (Melissen 2013).

Another issue for IR scholars to consider is the fundamental change that happens within diplomatic practices or diplomatic operations structures, per se. Melissen $(2013,196)$ insists that the societal dimension of diplomacy, meaning the "issues affecting citizens' daily lives that are far removed from classical diplomacy have moved upward on the agenda of foreign ministries and their diplomats." Rather than looking at traditional diplomacy and public diplomacy as entirely different practices, it is better to consider the two as inseparable. Traditional diplomatic techniques will always have an effect on public opinion, so public diplomacy must be incorporated into all diplomacy measures. In this respect, both 'communication to' and 'communication with' approaches are mandatory in contemporary diplomacy.

According to Gregory (2008), public diplomacy is the use of various strategic activities by governments and citizens, with the goal of creating increased awareness and understanding of attitudes and cultures. He further defines public diplomacy as the engagement in dialogue among people, institutions, and political leaders, after which the public opinions of policy decisions are taken into account. Public diplomacy also uses communication and action to influence behavior and attitudes. Arguing from a constructivist perspective, Peter van Ham (2008) suggests that the process of place branding-with its emphasis on the importance of values and ideas-should also be considered relevant, even vital, 
when considering public diplomacy. Sharp $(2005,106)$, using an instrumentalist approach, describes the process of public diplomacy as pursuing "direct relations with the people in a country" in order to "advance the interests and extend the values of those being represented." In yet another definition, Michael McClellan $(2004,234)$ emphasizes the strategic nature of "informational, cultural, and educational programming" in public diplomacy. The use of these programs, he explains, is to influence public opinion in a target country in order for its political leaders to more easily adopt policies and make decisions based on the advocate country's objectives.

This study argues that there has been a paradigm shift in public diplomacy after its American heritage; one which underpinned the significance of information and public opinion and turned it into an instrument of foreign policy primarily dealing with two-way communications in pursuit of soft power. Furthermore, that paradigmatic shift saw an evolution towards normative foreign policy goals and objectives by embracing most of the soft power resources while also looking beyond soft power. Figure 1 illustrates the nodal point of this paradigm shift in public diplomacy-from 'old' to 'new'-that is associated with the concept of soft power because soft power successfully bridged the gap between traditional diplomatic activities of 'old' public diplomacy (public information and cultural relations) in the formation and execution of foreign policy and 'new' public diplomacy (shared goals to cultivate credibility) with strategies for effectiveness (two-way communications to shape public opinion and reputation) in a contemporary context (the information age). In this nodal point of paradigm shift, this study discovered that the link between information and foreign policy brought scholarly attention to the field of communications and public relations, which extends to diplomatic functions, structures, actors, and drives the convergence of these modes of communication into public diplomacy.

Since this initiative on soft power, public diplomacy scholars and practitioners widely associate the term with their arguments concerning 'new' public diplomacy (Hocking 2005; Melissen 2005; Batora 2005; Potter 2009; Snow and Taylor 2008; d'Hooghe 2011; Fizpatrick 2011; Servaes 2012). In contrast, the notion of soft power in conjunction with public diplomacy has been criticized because soft power exhibited a fundamental contradiction between the concepts of new public diplomacy and influence (Nossel 2004; van Ham 2008; Hayden 2012; 2013; Pamment 2012). Meanwhile, a revised conceptualization of soft power resulted in various new and differentiated concepts of power: integrated power, meaning leading alliances and converging such divisions as defense, homeland security, diplomacy, energy, and foreign aid (Gilboa 2008); smart 
power, the combination of, or the balance between, hard and soft power (Gilboa 2008; Nye 2009; Kounalakis and Simonyi 2011; Litvinsky 2011); social power, the capacity to establish norms and rules where actors' actions interact (van Ham 2010; Melissen 2013). Other concepts include normative power (Manners 2002; Rasmussen 2009), which indicates specific mechanisms for normative diffusion, and civilian power (Kamminga 2013), which refers to the combination of development cooperation and public diplomacy efforts. Figure 2 visualizes how scholars have incorporated soft power and its sources into our understanding of new public diplomacy and further developed other concepts of power.

Figure 1. Nodal Point of Paradigm Shift in Public Diplomacy

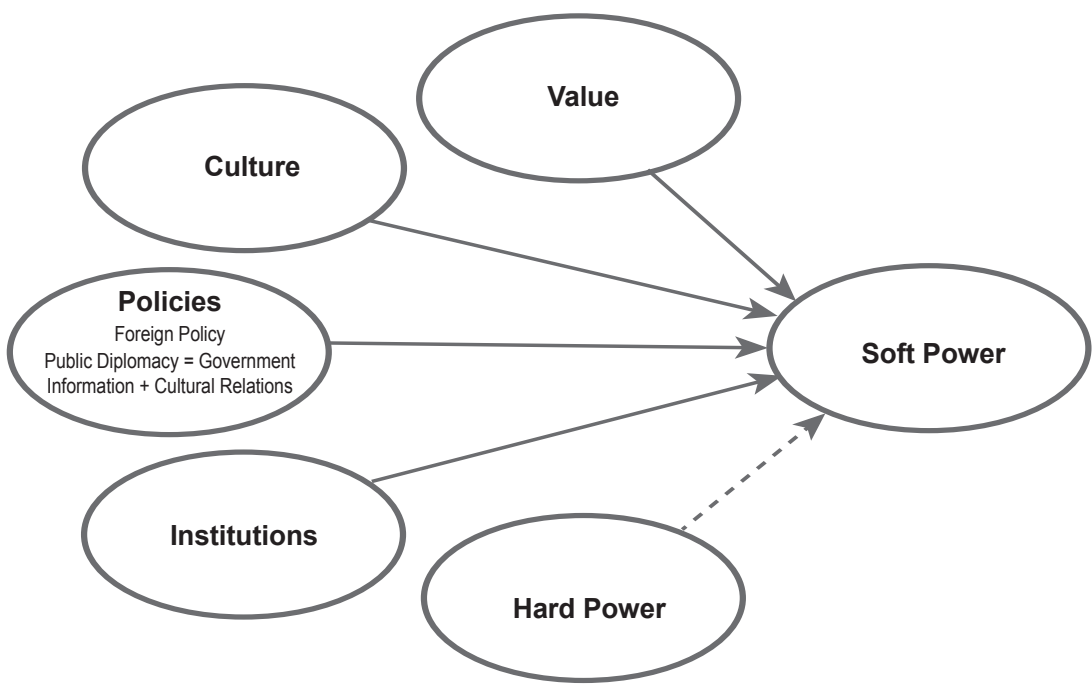

From an international relations standpoint, this study defines six characteristics of the new public diplomacy: (1) new public diplomacy is more than a technique of foreign policy, instead pursuing soft power; (2) new public diplomacy is primarily concerned with the international credibility of the nation-state; (3) new public diplomacy manages two-way and symmetric communications in the information age; (4) new public diplomacy pursues collaboration to achieve common goals; (5) new public diplomacy engages non-state actors and relates to multi-stakeholders and partnerships; and (6) new public diplomacy can cultivate a favorable diplomatic environment for 
a nation-state in world politics. This study defines new public diplomacy as a government's concerted efforts to achieve credibility, trust, and mutuality through two-way, symmetric communications to deal with public opinion between that government and foreign or global publics by engaging non-state actors and fostering partnerships as a means of embedding foreign policies with soft power.

Figure 2. New Public Diplomacy

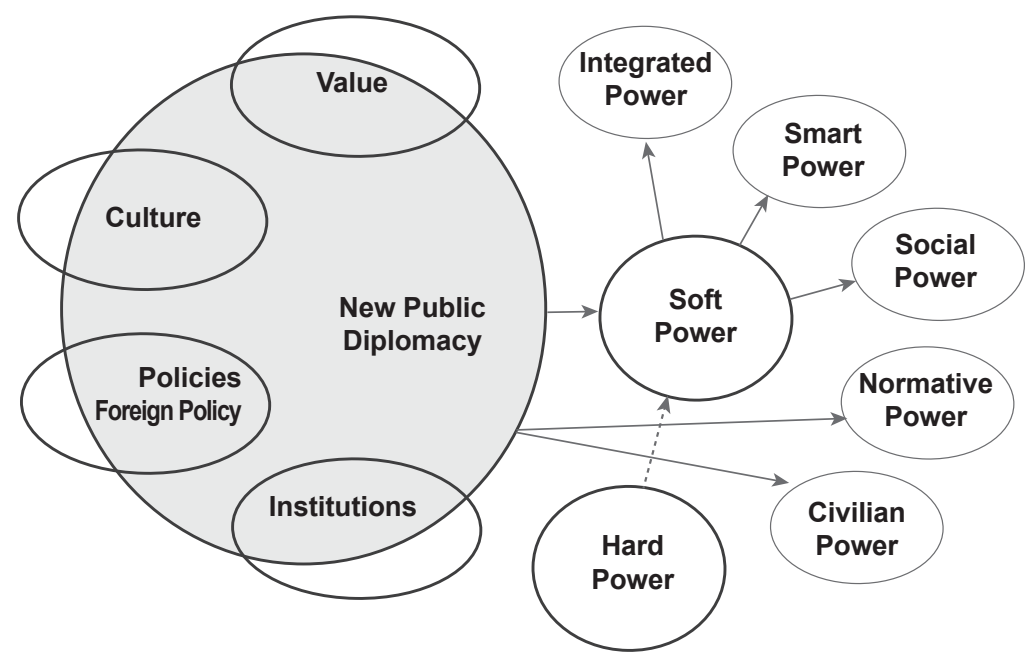

\section{UNCOVERING THE MISSING PIECES OF CULTURAL DIPLOMACY AS A SUBSET OF NEW PUBLIC DIPLOMACY}

There are four different views on the linkages between cultural diplomacy and public diplomacy, all of which vary from an academic standpoint. First, when defining 'engagement diplomacy,' Alan K. Henrikson (2005) omits concepts of public diplomacy and cultural diplomacy. Second, the 'contemporary diplomacy' of Zicheng and Qingmin (2013) deals with them in different domains. Third, Ordeix-Rigo and Duarte (2009) insist that cultural diplomacy can be regarded as grassroots public diplomacy, meaning cultural diplomacy is at the core of public diplomacy. Lastly, in explaining soft power, Nye (1990) mentioned cultural diplomacy and public diplomacy as tools for foreign policy to enhance 
soft power. He insists that, with the rise of globalization, cultural cohesion and cultural globalization mitigates the traditional meaning of cultural diplomacy because countries do not necessarily disseminate national identity through their promotion of cultural assets. As new public diplomacy has assumed a broader definition, cultural diplomacy has become a part of public diplomacy.

These different and conflicting conceptions of cultural diplomacy are often attributed to its lack of theoretical grounding (Arndt 2005; Entman 2008; Hudson 2007; Glade 2009). However, in the aftermath of the 9/11 attacks, the significance of the role of culture has been widely discussed by scholars as well as practitioners (Hudson 2007; Kennedy 2003; Kitsou 2013). This divergence raises the questions of how to define cultural diplomacy, what distinguishes cultural diplomacy from international cultural relations, and how to relate cultural diplomacy to public diplomacy. Since there are insufficient theoretical developments in the major schools of thought in IR, this study delves into three academic groups rather than taking a comparative approach: international historians, who provide fundamental research on culture in international affairs; IR perspectives, which explore the role of culture in world politics; and cultural diplomacy scholars, who fill the gaps between universalistic principles and limitations in practice.

\section{PERSPECTIVES OF INTERNATIONAL HISTORIANS}

A cultural approach to international history views culture as a dynamic process where people in similar cultures understand the world and form their perception in similar ways, which results in mutually understandable values (Costigliola 2004). The roles of culture in international affairs, especially those associated with cultural projection or cultural representation, can be found in the world exhibitions of the 19th century. Eckart Conze $(2003,199)$ particularly underlines the "functional" role of culture because those nation-states that participated in the world exhibitions sought to achieve international and foreign policy goals; subsequently, the connection between states, power, foreign policy, and culture became significant as governments "instrumentalized" culture for the purposes of spreading culturally-shaped images and enhancing "stability, security or even hegemony." Likewise, Wolfram Kaiser (2003) upholds the notion of instrumentalization of culture during the world exhibitions as a creation of a global public space where states strategically developed cultural representations by making images and messages that reached out internationally and competed with the images and messages of other countries.

According to Kaiser, the 19th century world exhibitions can be considered the birth of contemporary cultural diplomacy. National image promotion can 
be an important tool for states that do not have strong diplomatic connections or are outside of the status quo. France held the Paris exhibitions for years to create a more favorable image of the country and create competition between itself and Britain and Germany. Americans were more inept at this national image projection due to a lack of strategy as well as geographic isolation. France and Czarist Russia went to war in 1914 in part because of their ideological differences; however, their cultural representations also allowed future leaders to evaluate and make legitimate decisions based on these experiences in the international community. These international events provided opportunities for contesting foreign economics, social economics, and political economics, as well as social practices such as the French protective policy (Kaiser 2003).

On the other hand, Frank Costigliola (2004), taking culture as the production and exchange of meanings between members of a society or a group, signifies cultural affinities and throws open the door to cooperation, as shown in U.S. relations with Germany and France after the two world wars. Cultural beliefs playes a role in German verses French relations with the United States. Germany and America had similar attitudes on certain subjects, while France and America perceived the other to be dirty, ignorant, and disorganized. These relations had an effect on Germany's willingness to accept American guidance over the French.

Meanwhile, Guido Muller (2003) emphasized that culture helped to establish international networks among like countries, connect various actors involved in those networks, and to promote collaboration throughout two world wars. In addition, he suggested that culture was a subfield of European integration from approximately 1948 to the 1970 . Between the two world wars, a number of transnational organizations increased their international social and cultural relations. Two nongovernmental organizations were responsible for playing a role in Franco-German relations after 1918. Nongovernment workers strived to create networks for the reconstruction of Europe, forming relationships between France and Germany. These groups worked to exchange information and attain common goals, while hoping to influence the governments and political leaders of the time as well as to create a sense of European identity. From 1948 to the 1970s, the development of Europe had little influence from culture. Thus, historical cultural initiatives from before World War II were forgotten, but economic policies from that time were still readily available.

\section{PERSPECTIVES OF INTERNATIONAL RELATIONS SCHOLARS}

The historians' notion of the instrumentalization of culture fails to explain the relationship between power and culture, as Jessica C.E. Gienow-Hecht (2004, 276) criticizes their conceptualization for having a "limitation of political 
influence" because historians developed culture as an "all-inclusive category replacing the terms and the meaning of ideology." This limited their research on culture in international affairs. Through the lens of international relations, culture is more concerned with the "independent power of culture-the power of cultural preferences and conditions in the context of international relations," "globalization and multiculturalism," various actors encompassing private groups, businessmen, and artists, as well as ideas, products, and cultural confrontation in the context of the 9/11 attacks (Gienow-Hecht 2004, 276-278).

In particular, cultural internationalism, a subfield of cosmopolitan constructivism, contributes to theoretical development by reshaping the world order after the end of the Cold War. Akira Iriye $(1997,2004)$ takes this position and further develops the concept of cultural relations as opposed to the geopolitical approach-a Hobbesian formula of power and culture. Iriye insists that cultural communication in the context of a multicultural world enables the obtainment of mutual cultural understanding and "cross-cultural cooperation to deal with such global issues as environmental degradation, human rights, and demographic explosion," and defines culture as "structures of meaning," which include "memory, ideology, emotions, life styles, scholarly and artistic works, and other symbols" (Iriye 1997, 3). Iriye uses the term culture in the study of international relations as "the sharing and transmitting of consciousness within and across national boundaries" (2004, 215). The definition of cultural relations is "interactions, both direct and indirect, among two or more cultures. Direct interactions include physical encounters with people and objects of another culture. Indirect relations are more subtle, involving such things as a person's ideas and prejudices about another people, or cross-national influences in philosophy, literature, music, art, and fashion" (Iriye 2004, 242).

International relations can be seen as 'inter-cultural relations' in that every nation-state has its own culture. Nation-states and their inhabitants interact with other states in a number ways beyond their political or economic relations. It is still widely disputed as to whether these cultural dealings with one another helped to create interdependence or led to fragmentation on a global level (Iriye 2004). After World War I, international relations gained a cultural aspect as mutual understanding was promoted by nongovernment workers. Instead of wars and intimidation, states would exchange information on the arts and intellectual endeavors. Although these ideas were slightly premature, many nation-states have not lost sight of this vision in creating venues for international cooperation and communications among different cultures. The hope from these proponents was for a future where all nation-states followed these principles and promoted the creation of an international order (Iriye 2004). 
Picking up Iriye's notion of culture, Gienow-Hecht suggests that "culture affects nations and global systems as much as, if not more than, power and economic interests" $(2003,6)$ and underpins the concept of 'cultural transfer' as it associates culture with political influence $(2004,276)$. During the 1960 s and 1970s, some scholars believed that American culture was too prominent in other countries. However, this idea of cultural imperialism has been muted, as cultural interactions can be used to pursue a number of goals in cultural diplomacy. These beliefs changed in the 1980 os (Gienow-Hecht 2004).

Oliver Schmidt, taking a constructivist's perspective, insisted there was a cultural dimension to foreign policy in that culture could be regarded as 'a tool of diplomacy' because it could be "instrumentalized to achieve a state's goals through the foreign policy process" $(2003,177)$. Culture in diplomacy can be used as a tool for foreign policy, incorporating aspects from literature, films, music, and other cultural products. Culture in this sense is just part of a state's overarching foreign policy goals. Cultural imperialism, or forcing one's culture on another, is debatable as the history of the United States after 1945 shows some believe that the United States put effort into spreading American culture to secure influence in Europe. Conversely, a constructionist approach to the idea of cultural diplomacy is quite different. Since culture is seen as the underlying order that guides behaviors and beliefs, it is not merely a piece of diplomacy but the actual reason or cause of foreign policy. By using this broad definition of culture, Schmidt suggests that we can better understand and evaluate how diplomacy is influenced by culture.

In addition, César Villanueva Rivas specifies the notion of cosmopolitan constructivism in analyzing cultural and public diplomacy and succinctly defines it as "people, cultures and states matter, and cultural and public diplomacies collaborate in the inter-subjective construction of ideas, norms and identities towards cooperation, welfare and understanding" (2010, 48). Organizations and individual citizens can foster understanding and appreciation of other cultures, in a form of cosmopolitan constructivism. This shows the recognition that sustainable, friendly relations between states are the most important goals of diplomacy. These types of programs focus foreign policy resources on creating peace and promoting international education among countries, investing in infrastructure and independent foreign institutions for friendly exchanges, and establishing communications channels with foreign publics.

Although the study of the cultural approach to international relations has flourished under constructivists, there was a limit in that constructivists offered universalistic principles and it was rare to find those in the practices of cultural and public diplomacies worldwide. Valerie M. Hudson (2007), on the other 
hand, provides a different approach to the role of culture in international relations. By utilizing perspectives of foreign policy analysis, Hudson probes the strong linkage between culture and international relations where scholarly debate on culture has been neglected mainly because of power politics. Culture plays an interesting role in foreign policy as it is often used to describe what cannot be easily explained or to describe and predict future political action. This creates the need to study culture as a political tool and to understand culture in order to make decisions and foresee the effects of diplomatic strategies.

\section{PERSPECTIVES OF CULTURAL DIPLOMACY SCHOLARS}

As previously mentioned in Villanueva's conceptualization, recent IR scholars tend to link cultural diplomacy and public diplomacy. Indeed, cultural diplomacy, which frequently overlaps with public diplomacy, has been taking place for as long as traditional diplomacy though it has not always been seen to be as important. There always has been an exchange of ideas, art, religion, and cultural products during diplomatic transactions (Arndt 2005). This is because the spread of culture can facilitate economic activity, as well as value exchanges, leading to greater cooperation between states. However, a simple cultural exchange does not mean that cultural diplomacy is taking place. It must happen as part of a specific strategy. Nevertheless, the unpredictability of a common cultural exchange, though it may bring about positive outcomes for the country, makes it difficult to measure the results of such activities (Andreasen 2008). These ambiguities of cultural diplomacy drew scholarly attention to its history, definitions, activities, models, and so forth; eventually, the concept of cultural diplomacy was developed and theorized by only a few prominent cultural diplomacy scholars.

Anthony Haigh (1974) explained that international cultural relations were mostly carried out by private initiatives along with government support, such as in the case of Christopher Columbus's exploration of the Americas, but government-led initiatives, such as Captain Cook's explorations or Napoleon's expedition to Egypt, were rarer. Since it is a recent phenomenon for governments to approach culture for the purposes of commercial or political advantage, Haigh loosely defines cultural diplomacy as "the activities or governments in the sphere-traditionally left to private enterprise-of international cultural relations" and, therefore, it is "a technique which can be used for good purposes or bad" $(1974,28$.). In this respect, he implies that although there are pejorative connotations to cultural propaganda in the period encompassing the two world wars, it is merely the first phase of cultural diplomacy-the singular-and argues that there are subsequent phases-dual (bilateral cultural diplomacy) and plural 
(multilateral or collective cultural diplomacy). In comparison, Paschalidis (2009) outlines four phases in the historical development processes of cultural diplomacy: (1) cultural nationalism (1870-1914), when the global presence of cultural institutions such as the French, Italian, Goethe Institute, or the British Council arose; (2) cultural propaganda (1914-1945), the mobilization of intellectuals and artists in the service of official propaganda during World War I; (3) cultural diplomacy (1945-1989), the inter-war and the post-war phases as an extended period of cultural propaganda during the Cold War; and (4) cultural capitalism (1989-present), the demise of U.S. cultural relations abroad, unlike the EU's engagement with the cultural dimensions of the European integration process. At the beginning of the 21st century, such economic powers as Japan, China, and India developed them for different purposes, such as cultivating soft power.

As to the beginning of cultural diplomacy, Haigh traces it back to the 17th and 18th centuries in France when cultural diplomacy was dedicated to "the satisfaction of the Odysseus-motif of the learned men of France" towards nonFrench territories, the so-called "Napoleonic experiment" (1974, 31). During the 19th century, most European countries saw an increase in private institutions playing the lead role in their cultural influence abroad. Schools, churches, and cultural institutions were built in foreign countries with large expatriate populations. The French and Germans, however, were the first to understand and take advantage of the fact that these institutions could enhance cultural prestige abroad.

The difference between cultural relations and cultural diplomacy is more thoroughly outlined by Richard T. Arndt (2006). He distinguishes cultural relations, defined as those that "grow naturally and organically, without government intervention-the transactions of trade and tourism, student flows, communications, book circulation, migration, media access, intermarriagemillions of daily across-cultural encounters," from cultural diplomacy, that "take place when formal diplomats, serving national governments, try to shape and channel this natural flow to advance national interests" (Arndt 2006, xviii). He insists that cultural diplomacy started in the Bronze Age, since diplomacy in the 3rd millennium B.C. was advanced enough to allow for cooperation between communities, rather than all interactions involving the use of physical force. This allowed planning, cooperation, and reflection among a number of individuals, groups and, most importantly, cultures. Communication via messages, adapting to new technologies, and information proliferation allowed more open civilizations to maximize learning and cooperation. By the second half of the 17th century, France had set up semi-independent cultural units such 
as the foreign academy and an informal cultural adjunct to the embassy. French artists were trained at the foreign academy in Rome under Louis XIV in 1677. This academy was created to fill the void that was left after the death of Nicolas Poussin (1594-1665), who spent much of his life in the Roman embassy working to expand cultural and artistic knowledge. Not long after, foreign academies were established in countries around the world by a number of states.

Along with Haigh's historical tradition, Arndt not only focuses on how cultural diplomacy has been historically institutionalized by governments when defining cultural diplomacy, but he also emphasizes power and culture relations in his analysis. Gupta and Ferguson $(1997,17)$ provide the backbone for this notion, stating that "cultural distinctiveness" is produced "within a field of power relations" because otherness in politics is inevitable; for instance, the restriction of immigration shows how the disempowered are kept away in a spatially interconnected world. Cultural globalization can either be looked at as "a homogenizing process that takes away some aspects of identity from cultures" or as "a sharing process that allows certain dominant aspects of cultures to be taken in and transformed, to help cultures better link to the greater world" (Gupta and Ferguson 1997, 17). In this respect, Gupta and Ferguson argue that culture can additionally be created and transformed through political processes. Instead of simply being shared values and common interests, culture in this sense is understood through differences and contestations in its political domain. This notion can be closely linked to Hudson's notion of power as an element of culture and strong linkages between cultural analysis and power politics analysis.

\section{WHAT COMPLICATES THE DEFINITION OF CULTURAL DIPLOMACY?}

\section{CULTURAL DIPLOMACY ROOTED IN WESTERN EUROPEAN COUNTRIES}

The Western European model of cultural diplomacy has been extensively researched by Haigh (1974). France is the forerunner of cultural diplomacy, but this model only reaches the second phase of cultural diplomacybilateral cultural cooperation-in terms of governance and practice, up until the outbreak of World War II in 1939. In particular, the French government created a commission for French action and information abroad in 1936. This was attached to the Prime Minister's Office and coordinated with other ministries, including the Ministry of Foreign Affairs, and led to nineteen cultural conventions with thirteen foreign governments between 1919 and 1938.

The starting point can be traced back to late 18th century private initiatives. Similarly, the government of Germany created the Archaeological Institute in 
Rome in the 1870 , when private initiatives were in decline, and established a section for Arts and Science in the Ministry of Foreign Affairs in 1896, and a Schools Section in 1906. Italian schools and the Dante Alighieri Society were created after the 1880 s, but they did not receive any government support until the 1960s. Italian cultural institutes operated only during the Mussolini regime, when the Institute for Cultural Relations with Foreign Countries (IRCE) was created in 1938, but it was not merged into the Ministry of Foreign Affairs even under the fascist regime. The Goethe Institute was created in 1929 to promote German language in foreign countries, and the Nazis utilized cultural diplomacy in a subordinate role for disseminating ideological propaganda. Fascism, by combining political and cultural propaganda, spurred the British government to set up a committee for education purposes in 1920. A British Committee for Relations with Other Countries was established in 1934, and one year later it changed its name to the British Council. This council conducted the most successful "multilateral or collective cultural diplomacy," reaching Haigh's third phase (plural), due to its "two-way traffic" features, enabling it to collaborate with UNESCO in 1945 (Haigh 1974, 46-47).

Interest in creating positive, peaceful global relations after World War I saw cultural diplomacy being sought after and managed through educational and scientific collaborations and exchanges. America did this mostly through private institutions until the aggressive cultural diplomacy initiatives of Germany, the Soviet Union, and Japan began in the 1930s (Gregory 2008). This caused the United States to combine past private initiatives with new government-funded programs. After World War I, the United States, Soviet Union, and European countries were increasing their influence abroad through media and private cultural foundations. While the United States was just starting to link the areas of politics and communications, the Soviet Union had been using these connections for a number of years to enhance its national image abroad (Fox 2012).

In particular, the Soviet threat brought dramatic changes to cultural diplomacy. Michael David Fox (2012) stated that Soviet cultural diplomacy was bigger than either its culture or its diplomacy; rather, it was "the entire complex of missions the Soviet Union directed at the foreigners classified as members of the intelligentsia, both inside and outside the USSR" to be intensively associated with "propaganda, political-ideological leverage, and scientific technological development" $(2012,17)$. Against this backdrop, British propaganda was organized. After World War I, the British government saw cultural diplomacy as a tool for increasing the country's prestige in the Middle East. Using initiatives such as exchange programs, book distributions, and a prominent film industry, 
British influence grew and became even more significant after World War II, when the war-torn country wanted to continue projecting a strong national image (Vaughan 2005).

\section{U.S. CULTURAL DIPLOMACY}

The United States was not concerned with managing information and cultural exports until the creation of the State Department's Division of Cultural Affairs in 1938 (Fox 2012). There were two reasons behind this. First, private philanthropic and educational organizations took a significant role in disseminating ideas about the 'American way' in the early 2oth century (Ninkovich 1981). Second, the Committee on Public Information, established in 1917, managed cultural experts who had skills and experiences and who were able to "publicize the Wilsonian dream of a world made safe for democracy"; consequently, the Committee provided a foundation for the government's political and cultural propaganda throughout World War II, even though it was abolished in 1919 (Pells 1997, 8).

After World War II, the U.S. administration and media highlighted the country's 'greatness'; America's dominance during this time brought with its international responsibilities and the United States portrayed this in its diplomacy (Fousek 2000). From the 1950s to the 1970s, at the peak of U.S. cultural diplomacy, the U.S. government sent hundreds of entertainers, including actors, musicians, and artists, to perform in other countries (Schneider 2003). Cultural diplomacy and the rise of everything from music to movies, Fulbright fellowships to Voice of America broadcasts, sports diplomacy to interfaith dialogues, collectively "moved the meter" in terms of overseas understanding of American foreign policy (Sonenshine 2015, 16).

When the United States became a global power during the Cold War, cultural diplomacy became an important strategic tool of the USIA. Cultural initiatives overseas were covertly supported by the CIA well into the 1950s. By the end of the Cold War, however, much of the previous cultural diplomacy strategies were seen as unnecessary in the new era of mass electronic communications and technology. Most of the country's public diplomacy initiatives were cut. Even today, the budget for American culture-related activities is considered seriously underfunded (Finn 2003).

\section{CULTURAL DIPLOMACY LABLED AS A MEANS OF NEW PUBLIC DIPLOMACY}

Gienow-Hecht and Donfried (2010) raise questions about the confusion of using cultural diplomacy mixed with public diplomacy, cultural exchange, and 
propaganda. They categorize five perspectives: (1) cultural diplomacy associated with the Cold War; (2) distinction between cultural relations and cultural diplomacy; (3) cultural diplomacy as it differs from public diplomacy; (4) cultural diplomacy as a subset of public diplomacy; and (5) cultural diplomacy qualified as a state interest. In a broader sense, they reorganize these into three categories: first, cultural diplomacy as the tension between propaganda and diplomacy with limited participation from private actors; second, the use of cultural diplomacy as an instrument to work at the exclusion of politics; and third, cultural diplomacy beyond the realm of the state. This categorization shows how limited cultural diplomacy can be or how far it can be extended, but it fails to explain how to solve the confusion of the mixed usage of the term. As discussed in the previous section, public diplomacy scholars from both the fields of public relations and international relations tended to put cultural diplomacy in the category of public diplomacy activities. In contrast, Jorrit Kamminga (2013) argues that most of the public diplomacy practices in reality fall within cultural diplomacy because public diplomacy mainly deals with the use of cultural assets to support foreign policy and foster mutual understanding through such cultural exchanges as sports, literature, music, or science. Since public diplomacy has an American heritage, it is worthwhile to look at how both terms have intermingled in a U.S. context.

As noted, U.S. cultural diplomacy was rooted in the Committee on Public Information in 1917, including political and cultural propaganda, which was severely criticized by domestic politicians and the public even though it was abolished within only a few years. However, the tradition of U.S. cultural diplomacy can be found in the programs of the Committee, indicating that U.S.'s cultural diplomacy was attached as a subset of the Information Bureau, which conducted propagandistic missions funded by the CIA. However, in the 1930s, the United States had to conduct diplomatic actions against aggressive cultural diplomacy by Germany, the Soviet Union, and Japan, keeping them separate from the aforementioned civil society initiatives of philanthropic and educational organizations. Because of the need for government funds, as well as the effort for greater coordination, the voluntarily civil society initiatives yielded (Gregory 2008). The activities continued into the 1950 s within the USIA and then the public diplomacy section of the State Department after the abolishment of the USIA in 1999 (Nye 2008).

Therefore, cultural diplomacy and 'old' public diplomacy went through the same traumatic events, and eventually both gained pejorative connotations of being propaganda in U.S. foreign policy. As mentioned, the tradition of public diplomacy in the United States dealt with information, on the one hand, and 
with cultural engagement on the other; in that context, soft power provided common ground for both public diplomacy and cultural diplomacy creating a soft landing in the field of diplomacy. Because of this historical path, U.S. public diplomacy scholars were likely to place cultural diplomacy within the concept of public diplomacy, with more focus on communications.

Although public diplomacy is deeply rooted in American foreign policy, the term 'new' public diplomacy emerged from European scholars who emphasized the normative aspects of public diplomacy to address the inconsistences between what the United States said and what it did, as well as to facilitate the EU integration process. This study contemplates the idea that the new public diplomacy was enough to satisfy the then-future direction of U.S. foreign policy with appropriate rationale, while enhancing U.S. soft power abroad. This notion of conducting public diplomacy to gain soft power also informs the foreign policy initiatives of other countries. This implies that the link between soft power and new public diplomacy is a mélange of different aspirations for explaining and predicting the context of diplomatic operations affected by globalization and the ICT revolution, as well as prescribing the future direction of foreign policy in this increasingly interconnected world.

In the meantime, Western European (French, German, British, and Italian) cultural diplomacy took a different historical path as it was integrated into public diplomacy. In the beginning, Western European cultural diplomacy was facilitated under ministries of foreign affairs coordination to supplement the decline of private initiatives in the field of culture and education and to be against ideological opponents. As such, independent cultural institutions were set up under various ministries of foreign affairs. Over time, these institutions gained more autonomy while stepping away from foreign and domestic politics. Eventually, most of the cultural diplomacy activities in these countries evolved into the concept of international cultural relations and, thus, their cases have been regarded as successful cultural diplomacy because they reached the final phase of cultural diplomacy-multilateral as defined by Haigh (1974). Therefore, there was no need to put a new name to cultural diplomacy. Rather, Western European countries developed cultural diplomacy by creating new governance structures-independent cultural institutions-in order to coordinate cultural relations programs and activities abroad more effectively by engaging various non-state and private actors.

In this respect, this study argues that this new governance encouraged cultural agents in those institutions to take on similar roles as were requested of diplomats for new public diplomacy, engaging diverse non-state cultural actors both at home and abroad, building relationships and networks through two- 
way communication with foreign publics, and fostering mutual understanding and collaboration through partnerships. In considering the success of the British Council (Haigh 1974), this study found that the greater degree of autonomy the institution granted to its cultural agents, such as more responsibilities and the ability to act beyond national interests in international cultural relations, the more it generated a good image of the nation-state because of the distance from the government. Thus, genuine dialogue between home and foreign publics could be realized.

In short, the intricacies of the mixture of using those terms rely on two paradoxes. First, cultural diplomacy of those Western European countries has grown into a far broader concept within international cultural relations; whereas, the scope of cultural diplomacy in U.S. foreign policy diminished as it focused on information functions and ended up being integrated into public diplomacy within the State Department. Second, the European concept of new public diplomacy puts more weight on normative aspects with a far broader conceptualization than 'old' public diplomacy in the United States; meanwhile, the concept of soft power has helped to regain the importance of culture in foreign policy in conjunction with public diplomacy and cultural diplomacy.

Simon Mark (2009) defines cultural diplomacy as a subset of public diplomacy by distinguishing it from international cultural relations. Although both are considered elements of soft power, public diplomacy covers a wider range of diplomatic activities including government media management, public relations, and other activities aimed at foreign publics. He conceptualizes international cultural diplomacy in terms of similar practices to public diplomacy; however, international cultural diplomacy does not necessarily involve the government in activities that may contribute to foreign policy goals. This argument enables cultural diplomacy to be differentiated from propaganda. Rather, he emphasizes that cultural diplomacy contributes to supporting foreign policy and enhancing domestic cohesion aimed at promoting national domestic goals. In this regard, he also points out its contribution to state identity because the pursuit of cultural diplomacy can be defined in conjunction with national image or in pursuit of domestic objectives; thus, private actors, government involvement, objectives, activities, and audiences are mentioned as the core elements of cultural diplomacy in his argument (Mark 2010). Consequently, as distinguished from international cultural relations, cultural diplomacy has become a subset of new public diplomacy.

In an integrative manner, Mark explains how and why cultural diplomacy has become regarded as a subset of public diplomacy, but there still were some contradictions in his arguments. First, the discrepancy between international 
cultural relations and international cultural diplomacy was not clear because he argued that not all international cultural diplomacy involves a government. How then can we distinguish international cultural diplomacy from diplomacy without government involvement? Second, the meaning of diplomacy is distorted in his argument about cultural diplomacy's contribution to domestic social cohesion. Nevertheless, his definition of cultural diplomacy makes clear why and how new public diplomacy deals with cultural diplomacy.

\section{HOW TO DEFINE CULTURAL DIPLOMACY?}

After exploring the heyday of cultural diplomacy in the 17th and 18th centuries, expansionism from the 19th century until prior to World War I, and during and after the Cold War in the 2oth century, the evidence shows that it is probable that cultural diplomacy conducted by governments can be affected by the following elements: a government's approach to international cultural affairs, the relationship between cultural bureaus or cultural institutions and ministries of foreign affairs, and the existence of cultural institutions. According to Haigh, the success of cultural diplomacy depends on a cultural institution's performance and the degree of its autonomy and neutrality over time. In terms of structures and practices, more distance "between the agent of cultural diplomacy and the political or economic agenda" and more interactions "within the structure of cultural diplomacy" are keys to success (Gienow-Hecht and Donfried 2010, 23).

Also, it is important to note that most cultural diplomacy actions originated from private initiatives that the government picked up on after cultural affairs done by the private sector were in decline, which was in a time of expansionism or when the government needed to do political actions in opposition to ideological confrontations during the Cold War. Two things are implied. First, cultural diplomacy was politically driven not only as a means to seek power internationally, but also as an inbound or ethnic diaspora of cultural cohesiveness. Second, private actors have been at the core of cultural affairs in international relations from the beginning. The latter implication shows that a government's role in coordination impacts the effectiveness of cultural diplomacy.

Lastly, cultural diplomacy has been spurred on by the development of communications technology; originally with radio communications in the early 20th century to disseminate ideological messages against foes, and later with the ICT revolution in the late 20th century, which has been fostering globalization and cultural transfers. One issue to consider is how cultural diplomacy responds to cultural homogenization or fragmentation caused by globalization in the information age. 
The literature on cultural diplomacy reveals that there is no universally agreedupon definition of cultural diplomacy. Rather, the meaning of cultural diplomacy varies depending on the context. Therefore, this study firstly attempted to draw a historical outline on the basis of Paschalidis's (2009) four phases of cultural diplomacy: first, cultural nationalism (1870-1914); second, cultural propaganda (1914-1945); third, cultural diplomacy (1945-1989); and finally, cultural capitalism (1989-present).

In the first phase of cultural nationalism, this study highlighted the fact that private initiatives related to cultural relations and exchanges led to government-sponsored cultural diplomacy. As to the next phase of cultural diplomacy, this study suggests it should contain Iriye's (2004) views on cultural internationalism, the universality of shared values and concerns, the permanence of the commitment to promotion of cross-cultural communication, and cooperation. In particular, this phase adds to the role of culture as part of crisis conflict resolution, as Stoica and Pantea (2014) have suggested.

Secondly, this study pairs Haigh's (1974) three phases of institutional development regarding cultural diplomacy with Mark's (2009) definition of cultural diplomacy as distinguished from international cultural relations; however, this study does not use the concept of international cultural diplomacy. In that regard, this study defines cultural diplomacy in the contemporary context as the intersection between new public diplomacy and international cultural relations. Figure 3 delineates the overlapping area as cultural diplomacy, which is distinguished from private initiatives in international cultural relations and visualizes three phases over time that affect the next phase of development of cultural diplomacy, as the arrow indicates.

This study views 'private initiatives' as the origin of cultural diplomacy, dating back to the late 18th century when private individuals took initiatives for cultural exchanges between countries and mainly were conducted by Western Europeans. Private initiatives led to cultural propaganda, particularly during World War I and II and throughout the era of cultural imperialism during the Cold War. This is defined as 'old cultural diplomacy.' In this phase, governments took the lead to implement and execute cultural diplomacy through policy decision-makers and government officials. Then, what distinctions lie between old and new cultural diplomacy? Mainly, they have different goals and objectives. While 'old cultural diplomacy' has a clear ideological purpose, 'new cultural diplomacy' deals with the universality of shared values and concerns, as cultural internationalism expresses characteristics of cultural diplomacy in the contemporary era. Meanwhile, the conception of 'international cultural relations' includes not only 'private initiatives' but 'new cultural diplomacy,' which overlaps with 'new public 
diplomacy.'

Figure 3. New Cultural Diplomacy as an Intersectional Concept

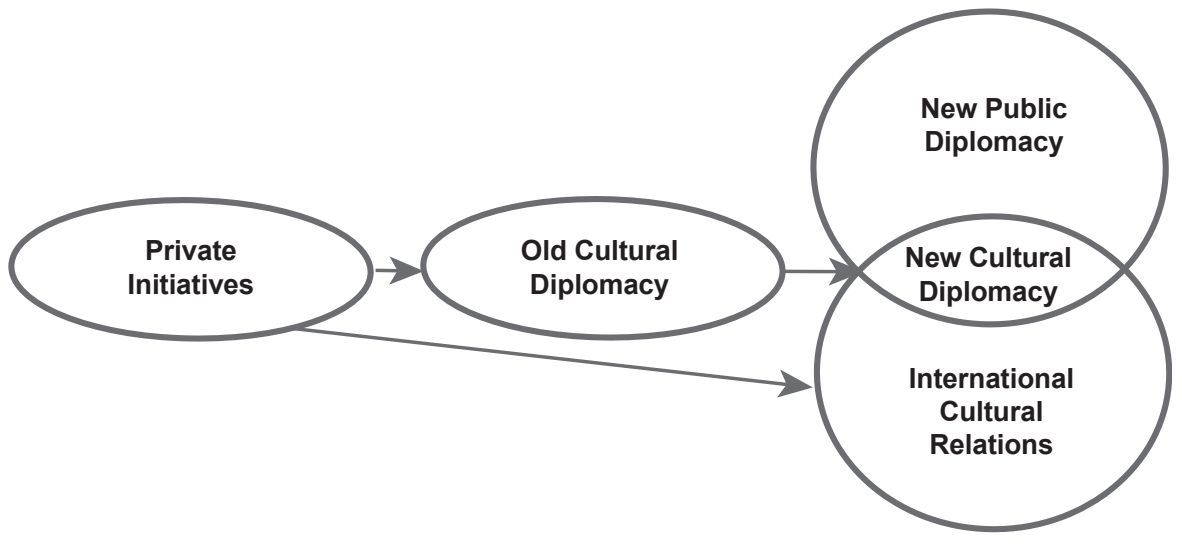

Therefore, this study supports the conceptualization of cultural diplomacy as a subset of new public diplomacy, as well as a subset of international cultural relations. Thus, new cultural diplomacy can be defined as a cultural actor's attempts to cultivate cultural understandings through international cultural relations in line with a government's concerted efforts to achieve credibility, trust, and mutuality with normative values and shared goals beyond national interests. Here the international cultural relations include such cultural exchange programs and activities as multicultural events, art exhibitions, performing arts concerts, popular cultural arts, international festivals, and others. In this conception, this study also classifies cultural actors into two groups: (1) cultural actors associated with new public diplomacy, such as governments, governmental agencies, and quasi-governmental institutions; and (2) cultural actors in conjunction with international cultural relations, particularly facilitated by private initiatives such as individual artists and personnel, commercial companies in art and culture, non-profit organizations, and non-governmental organizations. 


\section{CONCLUSION}

This study discussed scholarly debates about public diplomacy and cultural diplomacy. Against the backdrop of the Cold War, public diplomacy was considered merely as a substitute for propaganda and thus held pejorative connotations. As the information age arrived, diplomatic functions and systems have been challenged in the context of globalization. After the 9/11 attacks, there was a paradigm shift in diplomatic activities in association with information and communications, which gave rise to a new perspective on public diplomacy-new public diplomacy. Communications, international public relations, marketing, foreign policy analysis, diplomatic studies and their practitioners, were dedicated to developing the concept of the 'new' public diplomacy. However, this study finds that there are literature gaps as to what 'new' public diplomacy is and how it differs from 'old' public diplomacy.

After exploring the major arguments in the fields of communications, public relations, and international relations, it turns out that the concept of soft power provides common ground for scholarly debates on the nature of the new public diplomacy. This study defines the six characteristics of new public diplomacy as follows: (1) aiming to increase a country's soft power; (2) seeking international credibility for the country; (3) managing two-way and symmetric communications; (4) pursuing collaborations to achieve common goals; (5) engaging non-state actors and embracing multi-stakeholders and partnerships; and (6) cultivating a favorable diplomatic environment in world politics. In line with these six characteristics, this study insists that there is an additional point related to the role of government in conducting new public diplomacy, and so conceptualizes new public diplomacy as the concerted efforts of governments to win the hearts and minds of foreign publics and to include public diplomacy vis-à-vis domestic publics. However, this study disagrees with the notion of considering non-state actors as public diplomacy actors because it blurs the distinction between civilian diplomacy and public diplomacy.

In this respect, this study defines new public diplomacy as a government's concerted efforts to achieve credibility, trust, and mutuality through twoway, symmetric communications to deal with public opinion between that government and foreign or global publics by engaging non-state actors and fostering partnerships as a means of embedding foreign policies within soft power. Therefore, from the perspective of new public diplomacy, this study also considers different methods of, and tools for, conducting public diplomacy, such as media diplomacy, cyber diplomacy, aid diplomacy, cultural diplomacy, sports diplomacy, and so forth. 
In the previous section, this study uncovered the missing pieces in cultural diplomacy as a subset of new public diplomacy by exploring the perspectives of international historians, international relations scholars, and cultural diplomacy scholars. This enables the study to differentiate the historical development phases of cultural diplomacy from institutional development phases. This study also found that the concept of cultural diplomacy evolved into international cultural relations and embraced such cultural exchange programs and activities as multicultural events, art exhibitions, performing arts concerts, popular cultural arts, and international festivals regardless of whether they were public or private initiatives.

This study reveals that cultural diplomacy can be considered as an intersection between new public diplomacy and international cultural relations, and upholds the conception of new cultural diplomacy as a subset of new public diplomacy, as well as a subset of international cultural relations. This study defines new cultural diplomacy as a cultural actor's attempts to cultivate cultural understandings through international cultural relations in line with a government's concerted efforts to achieve credibility, trust, and mutuality. In doing so, this study contributes to building the theoretical concepts of new cultural diplomacy as a subset of public diplomacy by looking at different perspectives on new public diplomacy, soft power, cultural diplomacy, and international cultural relations. For future research, it is suggested that an examination of which schools of thought in international relations can best support and explain the concepts of new public diplomacy and new cultural diplomacy.

\section{REFERENCES}

Andreasen, Uffe. 2008. "Reflections on Public Diplomacy after the Danish Cartoon Crises: from Crisis Management to Normal Public Diplomacy Work.” The Hague Journal of Diplomacy 3(2), 201-207.

Arndt, Richard T. 2005. The First Resort of Kings: American Cultural Diplomacy in the Twentieth Century. Washington, D.C.: Potomac Books, Inc.

. 2006. "Rebuilding America's Cultural Diplomacy." Foreign Service Journal 83(10), 39-43.

Bachrach, Peter and Morton Baratz. 1962. "Two Faces of Power." The American Political Science Review 56(4), 947-952.

Batora, Jozef. 2005. "Multistakeholder Public Diplomacy of Small and Medium-Sized States: Norway and Canada Compared." Paper 
Presented to the International Conference on Multistakeholder Diplomacy, Mediterranean Diplomatic Academy, Malta (February 1113).

Bryce, James. 1889. The American Commonwealth, Volume 1. New York: Macmillan.

Conze, Eckart. 2003. "States, International Systems, and Intercultural Transfer: A Commentary.” In Jessica C.E. Gienow-Hecht and F. Schumacher eds., Culture and International History. New York: Berghahn Books, 198-205.

Costigliola, Frank. 2004. "Reading for Meaning: Theory, Language, and Metaphor." In Michael J. Hogan and Thomas G. Patterson eds., Explaining the History of American Foreign Relations. Cambridge, UK: Cambridge University Press, 279-303.

Cowan, Geoffrey and Amelia Arsenault. 2008. "Moving from Monologue to Dialogue to Collaboration: The Three Layers of Public Diplomacy." The Annals of the American Academy of Political and Social Science 616(1), 10-30.

Cross, Mai'A. Davis and Jan Melissen. 2013. European Public Diplomacy: Soft Power at Work. New York: Palgrave Macmillan.

Cull, Nicholas J. 2009. "Public Diplomacy Before Guillon: The Evolution of a Phrase." In Nancy Snow and Philip M. Taylor eds., Routledge Handbook of Public Diplomacy. New York and London: Routledge, 1923.

d'Hooghe, Ingrid. 2011. "The Limits of China's Soft Power in Europe: Beijing's Public Diplomacy Puzzle." In Sook Jong Lee and Jan Melissen eds., Public Diplomacy and Soft Power in East Asia. New York: Palgrave Macmillan, 163-190.

Entman, Robert M. 2008. "Theorizing Mediated Public Diplomacy: The US Case." The International Journal of Press/Politics 13(2), 87-102.

Finn, Helena K. 2003. "The Case for Cultural Diplomacy: Engaging Foreign Audiences." Foreign Affairs 82(6), 15-20.

Fitzpatrick, Kathy R. 2011. U.S. Public Diplomacy in a Post-9/11 World: From Messaging to Mutuality. Los Angeles, CA: Figueroa Press.

Fousek, John. 2000. To Lead the Free World: American Nationalism and the Cultural Roots of the Cold War. Chapel Hill, NC: The University of North Carolina Press.

Fox, Michael David. 2012. Showcasing the Great Experiment: Cultural Diplomacy and Western Visitors to the Soviet Union. Oxford, UK: Oxford University Press. 
Gienow-Hecht, Jessica C.E. 2003. "On the Diversity of Knowledge and the Community of Thought: Culture and International History." In Jessica C.E. Gienow-Hecht and F. Schumacher eds., Culture and International History. New York: Berghahn Books, 3-26.

. 2004. "Cultural Transfer." In Michael J. Hogan and Thomas G. Patterson eds., Explaining the History of American Foreign Relations. Cambridge, UK: Cambridge University Press, 257-278.

Gienow-Hecht, Jessica C.E., and Mark C. Donfried. 2010. "The Model of Cultural Diplomacy: Power, Distance, and the Promise of Civil Society." In Jessica C.E. Gienow-Hecht and Mark C. Donfried eds., Searching for Cultural Diplomacy. New York: Berghahn Books, 13-31.

Gilboa, Eytan. 2008. "Searching for a Theory of Public Diplomacy." The Annals of the American Academy of Political and Social Science 616(1), 55-77.

Glade, William. 2009. "Issues in the Genesis and Organization of Cultural Diplomacy: A Brief Critical History." The Journal of Arts Management, Law, and Society 39(4), 240-259.

Gregory, Bruce. 2008. "Public Diplomacy: Sunrise of an Academic Field." The Annals of the American Academy of Political and Social Science 616(1), 274-290.

Gupta, Akhil and James Ferguson. 1997. "Culture, Power, Place: Ethnography at the End of an Era." In Akhil Gupta and James Ferguson eds., Culture, Power, Place: Explorations in Critical Anthropology. Durham, NC: Duke University Press, 1-31.

Haigh, Anthony. 1974. Cultural Diplomacy in Europe. Council for Cultural Cooperation, Strasbourg (France): Manhattan Publishing Company.

Hayden, Craig. 2012. The Rhetoric of Soft Power: Public Diplomacy in Global Contexts. Lanham, MD: Lexington Books. . 2013. "Logics of Narrative and Networks in US Public Diplomacy: Communication Power and US Strategic Engagement." Journal of International Communication 19(2), 196-218.

Henrikson, Alan K. 2005. "Niche Diplomacy in the World Public Arena: The Global 'Corners' of Canada and Norway." In Jan Melissen ed., The New Public Diplomacy: Soft Power in International Relations. Hampshire: Palgrave Macmillan UK, 67-87.

Hocking, Brian. 2005 "Rethinking the 'New' Public Diplomacy." In Jan Melissen ed., The New Public Diplomacy: Soft Power in International Relations. Hampshire: Palgrave Macmillan UK, 28-43.

Hudson, Valerie M. 2007. Foreign Policy Analysis Classic and Contemporary 
Theory. Lanham, MD: Rowman \& Littlefield Publishers.

Iriye, Akira. 1997. Cultural Internationalism and World Order. Baltimore, MD: Johns Hopkins University Press.

2004. "Culture and International History." In Michael J. Hogan and Thomas G. Patterson eds., Explaining the History of American Foreign Relations. Cambridge, UK: Cambridge University Press, 241-256.

Jönsson, Christer and Martin Hall. 2003. "Communication: An Essential Aspect of Diplomacy.” International Studies Perspectives 4(2), 195-210. Kaiser, Wolfram. 2003. "The Great Derby Race: Strategies of Cultural Representation at Nineteenth-Century World Exhibitions." In Jessica C.E. Gienow-Hecht and F. Schumacher eds., Culture and International History. New York: Berghahn Books, 45-59.

Kamminga, Jorrit. 2013. "Public Diplomacy in Afghanistan Beyond the 2014 Transition: Lessons from the United States and the Netherlands." Netherlands Institute of International Relations Clingendael. Accessed at https://www.clingendael.nl/sites/default/files/Public\%20 Diplomacy\%20in\%20Afghanistan\%2obeyond\%20the\%202014\%20 Transition.pdf (March 20, 2016).

Kennedy, Liam. 2003. "Remembering September 11: Photography as Cultural Diplomacy.” International Affairs 79(2), 315-326.

Kim, Hwajung. 2011. "Cultural Diplomacy as the Means of Soft Power in an Information Age." Institute for Cultural Diplomacy. Accessed at http://www.culturaldiplomacy.org/pdf/case-studies/Hwajung_ Kim_Cultural_Diplomacy_as_the_Means_of_Soft_Power_in_the_ Information_Age.pdf (March 20, 2016).

Kitsou, Sofia. 2013. "The Power of Culture in Diplomacy: The Case of US Cultural Diplomacy in France and Germany." Exchange: The Journal of Public Diplomacy 2(1), 21-39.

Kounalakis, Markos and Andras Simonyi. 2011. The Hard Truth about Soft Power. Los Angeles, CA: Figueroa Press.

Leonard, Mark. 2002. Public Diplomacy. London: Foreign Policy Centre.

L'Etang, Jacquie. 2009. "Public Relations and Diplomacy in a Globalized World: An Issue of Public Communication.” American Behavioral Scientist 53(4), 607-626.

Litvinsky, Marina. 2011. European Union Public Diplomacy: The Need for a New Frame. The George Washington University, ProQuest Dissertations Publishing.

Manners, Ian. 2002. "Normative Power Europe: a Contradiction in Terms?" Journal of Common Market Studies 40(2), 235-258. 
Mark, Simon. 2009. “A Greater Role for Cultural Diplomacy.” Netherlands Institute of International Relations Clingendael. Accessed at https:// www.clingendael.nl/sites/default/files/20090616_cdsp_discussion_ paper_114_mark.pdf (March 20, 2016).

. 2010. "Rethinking Cultural Diplomacy: The Cultural Diplomacy of New Zealand, the Canadian Federation and Quebec." Political Science 62(1), 62-83.

McClellan, Michael. 2004. "Public Diplomacy in the Context of Traditional Diplomacy." PDAA(An Association of Public Diplomacy Professionals). Accessed at http://www.publicdiplomacy.org/45.htm (March 20, 2016).

Melissen, Jan, ed. 2005. The New Public Diplomacy: Soft Power in International Relations. New York Palgrave Macmillan. . 2013. "Public Diplomacy." In Pauline Kerr and Geoffrey Wiseman eds., Diplomacy in a Globalizing World: Theories and Practices. Oxford, UK: Oxford University Press, 192-208.

Muller, Guido. 2003. "France and Germany after the Great War: Businessmen, Intellectuals and Artists in Nongovernmental European Networks." In Jessica C.E. Gienow-Hecht and F. Schumacher eds., Culture and International History. New York: Berghahn Books, 97-114.

Ninkovich, Frank A. 1981. The Diplomacy of Ideas: US Foreign Policy and Cultural Relations, 1938-1950. Cambridge, UK: Cambridge University Press.

Nossel, Suzanne. 2004. "Smart Power." Foreign Affairs 83(2), 131-142.

Nye, Joseph S. 1990. "The Changing Nature of World Power." Political Science Quarterly Academy of Political Science 105(2), 177-192.

. 2002. "The Information Revolution and American Soft Power." Asia Pacific Review 9(1), 60-76.

. 2004. Soft Power: The Means to Success in World Politics. New York: Public Affairs.

. 2008. "Public Diplomacy and Soft Power." The Annals of the American Academy of Political and Social Science 616(1), 94-109.

. 2009. "Get Smart: Combining Hard and Soft Power." Foreign Affairs 88(4), 160-163.

. 2011. The Future of Power. New York: Public Affairs.

Ordeix-Rigo, Enric and João Duarte. 2009. "From Public Diplomacy to

Corporate Diplomacy: Increasing Corporation's Legitimacy and Influence." American Behavioral Scientist 53(4), 549-564.

Pamment, James. 2011. The Limits of the New Public Diplomacy: Strategic 
Communication and Evaluation at the US State Department, Foreign \& Commonwealth Office, British Council, Swedish Foreign Ministry and Swedish Institute. Department of Journalism, Media and Communication (JMK): Stockholm University.

. 2012. "Did Public Diplomacy Kill the British Council?" EInternational Relations (December 22). Accessed at http://www. e-ir.info/2012/12/22/did-public-diplomacy-kill-the-british-council/ (March 20, 2016).

Paschalidis, Gregory. 2009. "Exporting National Culture: Histories of Cultural Institutes Abroad.” International Journal of Cultural Policy 15(3), 275289.

Pells, Richard. 1997. Not Like US. New York: Basic Books.

Pigman, Geoffrey Allen and Anthony Deos. 2008. "Consuls for Hire: Private Actors, Public Diplomacy." Place Branding and Public Diplomacy 4(1), 85-96.

Potter, Evan H. 2009. Branding Canada: Projecting Canada's Soft Power through Public Diplomacy. Montreal \& Kingston, London, Ithaca: McGill-Queen's Press-MQUP.

Rasmussen, Steffen Bay. 2009. "Discourse Analysis of EU Public Diplomacy: Messages and Practices." Netherlands Institute of International Relations Clingendael. Assessed at https://www.clingendael.nl/sites/ default/files/20090700_cdsp_discussion_paper_115_Rasmussen.pdf (March 20, 2016).

Roberts, Walter R. 2006. "The Evolution of Diplomacy." Mediterranean Quarterly 17(3), 55-64.

Russell, Bertrand. 1967. War Crimes in Vietnam. London: Allen \& Unwin.

Sanders, Barry A. 2011. A Strategic Approach to U.S. Public Diplomacy. Los Angeles, CA: Figueroa Press.

Schneider, Cynthia P. 2003. "Diplomacy that Works: 'Best Practices' in Cultural Diplomacy." Center for Arts and Culture. Accessed at http:// www.americansforthearts.org/sites/default/files/Schneider.pdf (March 20, 2016).

Schmidt, Oliver. 2003. "Small Atlantic World: U.S. Philanthropy and the Expanding International Exchange of Scholars after 1945.” In Jessica C.E. Gienow-Hecht and F. Schumacher eds., Culture and International History. New York: Berghahn Books, 115-134.

Servaes, Jan. 2012. "Soft Power and Public Diplomacy: The New Frontier for Public Relations and International Communication between the US and China." Public Relations Review 38(5), 643-651. 
Sharp, Paul. 2005. "Revolutionary States, Outlaw Regimes and the Techniques of Public Diplomacy.” In Jan Melissen ed., The New Public Diplomacy. New York: Palgrave Macmillan, 106-123. . 2013 "Diplomacy in International Relations Theory and Other Disciplinary Perspectives." In Pauline Kerr and Geoffrey Wiseman eds., Diplomacy in a Globalizing World: Theory and Practices. Oxford, UK: Oxford University Press, 51-67.

Signitzer, Benno H. and Timothy Coombs. 1992. "Public Relations and Public Diplomacy: Conceptual Convergence.” Public Relations Review 18(2), 137-147.

Snow, Nancy and Philip M. Taylor, eds. 2008. Routledge Handbook of Public Diplomacy. Routledge.

Sonenshine, Tara D. 2015. "Is "Soft Power" Smart and Does It Work?" Public Diplomacy Magazine. Accessed at http://publicdiplomacymagazine. com/wp-content/uploads/2015/o6/Smart-Power-PD-Mag.pdf (March 20, 2016).

Stoica, Alina and Dana Pantea. 2014. "The Role of Cultural Diplomacy in Contemporary Crises and Conflict Reconciliation." Studia Universitatis Babes-Bolyai-Studia Europaea 1, 219-230.

Tuch, Hans N. 1990. Communicating with the World: US Public Diplomacy Overseas. New York: St. Martin's Press.

Van Ham, Peter. 2008. "Place Branding: The State of the Art." Annals of the American Academy of Political and Social Science 616(1), 126-149. . 2010. Social Power in International Politics. London, UK: Routledge.

Vaughan, James R. 2005. "A Certain Idea of Britain: British Cultural Diplomacy in the Middle East, 1945-57." Contemporary British History 19(2), 151-168.

Vikers, Rhiannon. 2004. "The New Public Diplomacy: Britain and Canada Compared." British Journal of Politics and International Affairs 6(2), 182-194.

Villanueva Rivas, César. 2010. "Cosmopolitan Constructivism: Mapping a Road to the Future of Cultural and Public Diplomacy." Public Diplomacy Magazine. Accessed at http://www.publicdiplomacymagazine.com/ cosmopolitan-constructivism-mapping-a-road-to-the-future-ofcultural-and-public-diplomacy/ (March 20, 2016).

Zaharna, Rhonda S. 2010. Battles to Bridges: U.S. Strategic Communication and Public Diplomacy after 9/11. New York: Palgrave Macmillan.

Zicheng, Ye and Zhang Qingmin. 2013. "China's Contemporary Diplomacy.” In Pauline Kerr and Geoffrey Wiseman eds., Diplomacy in a Globalizing 
The Korean Journal of International Studies 15-2 | 326

World: Theories and Practices. Oxford, UK: Oxford University Press, 282-299.

[Received February 10, 2017; Revised May 31, 2017; Accepted June 13, 2017] 